\title{
IMPLEMENTASI PEMBELAJARAN TEMATIK BERBASIS ICT UNTUK PENANAMAN SIKAP, PENGETAHUAN, DAN KETERAMPILAN PEDULI LINGKUNGAN BAGI SISWA SEKOLAH DASAR DI KOTA BENGKULU
}

\author{
Oleh:
}

Endang Widi Winarni, Sri Dadi, dan Yudi Setiawan

\begin{abstract}
ABSTRAK
Tujuan kegiatan pengabdian IbM adalah mendeskripsikan: (1) keterlaksanaan pembelajaran tematik menggunakan media berbasis ICT, (2) sikap, pengetahuan, dan keterampilan siswa tentang peduli lingkungan. Subjek kegiatan adalah guru dan siswa kelas V SDN 04 dan 20 Kota Bengkulu tahun 2016/2017. Kegiatan pengabdian dilaksanakan melalui dua cara yaitu pembelajaran in-door berbasis ICT dan out-door di Taman Satwa Kota Bengkulu. Teknik pengumpulan data siswa tentang lingkungan hidup menggunakan lembar observasi dan tes. Teknik analisis data secara kualitatif yaitu menggunakan persentase. Simpulan dari kegiatan adalah: (1) pelaksanaan pembelajaran tematik menggunakan media berbasis ICT secara in-door termasuk kategori sangat baik sedangkan yang secara out-door dengan kategori baik, dan (2) Pelaksanaan pembelajaran tematik terintegrasi PLH dan pelestarian biodiversity dapat: (a) mengembangkan sikap social siswa yaitu peduli lingkungan, disiplin, tanggungjawab, dan kreatif. (b) Pengetahuan siswa tentang kehidupan hewan karnivora, herbivora, dan omnivora. (c) Keterampilan siswa membuat teks penjelasan tentang hewan karnivora, herbivora, dan omnivora, mengisi tabel, membuat laporan pengamatan, dan membuat gambar dengan terampil (garis, bentuk dan warna).
\end{abstract}

Kata kunci: pembelajaran tematik, in-door dan out-door, berbasis ICT

\section{PENDAHULUAN}

Perilaku belajar anak sangat dipengaruhi oleh aspek-aspek dari dalam dirinya dan lingkungannya. Kedua hal tersebut tidak mungkin dipisahkan karena pembelajaran terjadi dalam konteks penemuan secara aktif oleh anak. Pembelajaran tematik integratif merupakan pendekatan pembelajaran yang mengintegrasikan berbagai kompetensi dari berbagai mata pelajaran ke dalam berbagai tema. Winarni, dkk (2014) menyatakan bahwa penanaman kesadaran dan kepedulian terhadap lingkungan hidup melalui sekolah penting dimulai sedini mungkin, dengan harapan ketika siswa menjadi dewasa dan menjadi pelaku pembangunan ataupun memiliki posisi sebagai pengambil keputusan, maka setiap kegiatan dan keputusan yang dilakukan akan selalu mencerminkan sifat, sikap dan perilaku berwawasan lingkungan.

Salah satu kompetensi di SD adalah penanaman kesadaran dan kepedulian terhadap lingkungan hidup. Kompetensi tersebut dikembangkan secara otentik dan kontekstual, 
dengan harapan siswa memiliki sikap peduli lingkungan. Upaya PLH diharapkan berdampak nyata bagi pengembangan watak dan perilaku yang ramah dan peduli lingkungan. Isu-isu PLH lokal yang sehari-hari dihadapi oleh masyarakat harus dikemas dalam pembelajaran, salah satunya melalui pembelajaran tematik terintegrasi bagi siswa SD.

Pada sisi yang lain, kemajuan IPTEK yang berkembang pesat pada saat ini dan harus dikuasai oleh bangsa Indonesia adalah adanya Teknologi Informasi dan Komunikasi Information and Communication Technology (ICT). Penggunaan ICT dalam bentuk media komputer diharapkan dapat peningkatkan efisiensi dan efektivitas pendidikan. Melalui pembelajaran terprogram dapat membantu proses belajar mandiri. Alternatif pelaksanaan pendidikan PLH adalah terintegrasi ke dalam pembelajaran tematik terpadu berbasis ICT secara in-door dan out-door berbasis lingkungan bagi siswa sekolah dasar. Berdasarkan uraian di atas, maka rumusan masalahnya adalah: (1) Bagaiamana keterlaksanaan pembelajaran tematik menggunakan media berbasis ICT? dan (2) Bagaimana sikap, pengetahuan, dan keterampilan siswa tentang peduli lingkungan? Tujuan kegiatan adalah mendeskripsikan: (1) keterlaksanaan pembelajaran tematik menggunakan media berbasis ICT, dan (2) sikap, pengetahuan, dan keterampilan siswa tentang peduli lingkungan siswa.

Secara ekologi manusia adalah bagian dari lingkungan hidup. Untuk kelangsungan hidupnya, manusia membutuhkan sumber daya dari lingkungan, sehingga hubungan antara manusia dan lingkungan tidak dapat dipisahkan. Kondisi lingkungan saat ini menunjukkan gejala munculnya berbagai macam polusi, panas global, ancaman kepunahan keanekaragaman hayati, dan lenyapnya hutan di Indonesia sudah sangat serius. Setiap anak memiliki cara tersendiri dalam menginterpretasikan dan beradaptasi dengan lingkungan (Winarni, dkk, 2015). Pemahaman tentang objek tersebut berlangsung melalui proses asimilasi (menghubungkan objek dengan konsep yang sudah ada dalam pikiran) dan akomodasi (proses memanfaatkan konsep-konsep dalam pikiran untuk menafsirkan objek). Kedua proses tersebut jika berlangsung terus menerus membuat pengetahuan lama dan pengetahuan baru menjadi seimbang. Dengan cara seperti itu secara bertahap anak dapat membangun pengetahuan melalui serangkaian penemuan secara nyata

Ketersediaan media berbasis komputer sangat pending untuk merangsang perhatian siswa, membangkitkan motivasi belajar, membantu mempermudah pemahaman siswa yang diberikan informasi dan dapat diulang dalam waktu lain. Interaksi anatara siswa, guru, dan media ini merupakan wujud nyata dari tindakan belajar. Belajar terjadi ketika siswa berinteraksi dengan media, tanpa media, proses belajar mengajar belum dapat berjalan secara optimal.

\section{METODE PENGABDIAN}

Subjek kegiatan adalah guru dan siswa kelas V SDN 04 dan 20 Kota Bengkulu tahun ajaran 2016/2017. Kegiatan IbM dilaksanakan melalui kegiatan observasional dan 
modelling dengan empat fase, yaitu: Fase perhatian, berkaitan dengan: (1) pemahaman tentang PLH dan biodiversity berbasis ICT, (2) pelaksanaan PLH dan biodiversity berbasis ICT, (3) penyiapan perangkat pembelajaran PLH dan biodiversity berbasis ICT, dan (4) penyiapan instrumen untuk mengukur sikap, keterampilan, dan pengetahuan berkaitan dengan kesadaran lingkungan hidup dan biodiversity. Fase retensi, dilakukan simulasi dan pelaksanaan pembelajaran PLH dan biodiversity berbasis ICT oleh tim IbM. Fase reproduksi, pada fase ini guru SD sebagai mitra telah menunjukkan kemampuan menjadi model baru. Fase motivasi, guru mitra merancang pembelajaran dan instrumen evaluasi pembelajaran PLH dan biodiversity berbasis ICT. Teknik pengumpulan data dalam kegiatan IbM ini adalah observasi, dokumentasi, tes, dan penyebaran angket/kuesioner. Teknik analisis data dilakukan secara deskriptif.

\section{HASIL DAN PEMBAHASAN}

\section{Pelaksanaan Pembelajaran Tematik Terintegrasi PLH dan biodiversity}

Hasil analisis kurikulum pada kelas V SD, Tema 6. Organ Tubuh Manusia dan Hewan. Sub Tema: 2 Organ Tubuh manusia dan hewan. Pembelajaran ke-1 mencakup mata pelajaran: (1) IPA dengan indicator sikap menunjukkan sikap rasa ingin tahu dalam mengenal makhluk hidup di lingkungan sekitar. (2) Bahasa Indonesia dengan indicator menunjukkan sikap tanggungjawab terhadap makhluk hidup di lingkungan sekitar melalui pemanfaatan bahasa Indonesia. (3) Matematika dengan indicator menunjukkan sikap disiplin dalam mengelola waktu untuk pergi ke tempat tertentu dengan mempertimbangkan jarak dan kecepatan. Pembelajaran ke-4 mencakup mata pelajaran: (1) SBdP dengan indikator Menunjukkan sikap peduli lingkungan terhadap makhluk hidup di alam sekitar melalui karya seni. (2) IPA dengan indikator Menunjukkan sikap cermat dalam memahami hewan piaraan yang tergolong mamalia di lingkungan sekitar. (3) Bahasa Indonesia dengan indikator menunjukkan sikap tanggung jawab terhadap makhluk hidup di lingkungan sekitar melalui pemanfaatan bahasa Indonesia.

Hasil analisis yang lainnya adalah Tema 8 Ekosistem dan Subtema 2 Hubungan Makhluk Hidup dalam Ekosistem mencakup mata pelajaran: (1) SBdP dengan indicator menunjukkan sikap peduli lingkungan terhadap makhluk hidup di alam sekitar melalui karya seni. Materi pelajaran IPA tentang jenis hewan berdasarkan penggolongan makanan. Materi pelajaran Matematika tentang konsep kecepatan sebagai hasil bagi antara jarak dan waktu. Materi Bahasa Indonesia tentang mengumpulkan informasi teks penjelasan tentang hewan karnivora, herbivora, dan omnivora. Materi pelajaran SBdP tentang membuat gambar hewan sesuai dengan garis, bentuk dan warna.

Workshop pembuatan media animasi mencakup dua bagian, yaitu video animasi bahan belajar dan video animasi untuk permainan. Video animasi bahan belajar meliputi: (1) mengenal jenis hewan langka, hewan peliharaan atau tidak langka, (2) tempat hidup 
atau habitat hewan, (3) ciri-ciri hewan berdasarkan kulit luar, cara bergerak, dan suara, (4) kelompok hewan berdasarkan jenis makanannya (herbivora, karnivora, dan omnivora). Sedangkan video animasi untuk permainan mencakup: (1) tebak suara hewan, (2) tebak hewan langka dan tidak langka, (3) tebak kelompok hewan berdasarkan jenis makanannya.

Peserta workshop adalah guru-guru dari SDN 20 dan SDN 04 Kota Bengkulu yang berjumlah 24 orang dilaksanakan di SDN 20 Kota Bengkulu pada tanggal 13 sampai 21 Mei 2016. Workshop perancangan perangkat pembelajaran tematik integratif meliputi: (1) pembuatan jaringan tema dan sub tema, (2) penyusunan silabus, (3) penyusunan RPP, (4) penyusunan Lembar Kerja Siswa (LKS), dan (5) penyusunan instrument penilaian aspek sikap, pengetahuan, dan keterampilan. Sebelum dilaksanakan sosialisasi dan pendampingan penyusunan kepada guru-guru sebagai peserta workshop diberikan tes awal.

\section{Pembelajaran tematik berbasis lingkungan di SDN 20 Kota Bengkulu.}

Pelaksanaan pembelajaran tematik terintegrasi PLH dan biodiversity di SDN 20 dilaksanakan dimulai dari persiapan lapangan dan atribut, pembelajaran out-door, kemudian pembelajaran in-door. Pendekatan pembelajaran yang digunakan adalah saintifik, model pembelajaran discovery learning, dan metode penugasan, tanya jawab, dan kerja kelompok. Sumber belajar yang digunakan adalah hewan-hewan yang ada di "Taman Satwa Bengkulu" meliputi: (1) posko I terdiri atas burung bangau Tong-Tong, Enggang, dan Pecuk Ular, (2) posko II rusa totol, (3) posko III siamang, beruk, dank era, (4) posko IV rusa timor dan buaya, (5) posko V burung hantu dan ular phiton, (6) posko VI musang, biawak, dan kura-kura. Pembelajaran diakhiri dengan kegiatan: (1) Siswa merefleksi terhadap aktivitas yang sudah dilakukan. (2) Siswa mengerjakan evaluasi. Dan (3) Siswa menyimak tindak lanjut yang disampaikan guru.

\section{Pembelajaran tematik berbasis ICT di SDN 04 Kota Bengkulu.}

Pelaksanaan pembelajaran tematik terintegrasi PLH dan biodiversity di SDN 04 Kota Bengkulu dilaksanakan in-door pada hari Kamis tanggal 6 Oktober 2016. Pendekatan pembelajaran yang digunakan adalah saintifik, model pembelajaran discovery learning, dan metode penugasan, tanya jawab, dan kerja kelompok. Media yang digunakan: (1) Video Animasi pembelajaran, (2) Foto-foto hewan yang ada di Taman Satwa Bengkulu, (3) video animasi game atau permainan tebak jenis makanan, (4) Bagan tentang hubungan kecepatan, jarak, dan waktu. (5) Teks tentang hewan karnivora, herbivora, dan omnivora. Pembelajaran diakhiri dengan kegiatan: (1) Siswa merefleksi terhadap aktivitas yang sudah dilakukan. (2) Siswa mengerjakan evaluasi. Dan (3) Siswa menyimak tindak lanjut yang disampaikan guru.

\section{Peningkatan sikap, pengetahuan, dan keterampilan siswa tentang lingkungan hidup dan biodiversity}

Sikap, Pengetahuan, dan Keterampilan Siswa SDN 20 Kota Bengkulu 
Penilaian sikap digunakan lembar observasi meliputi:

1) Peduli Lingkungan dengan indikator: (a) Membiasakan memungut sampah yang terlihat di sekitar sekolah dan Taman Satwa Bengkulu. (b) Memilih membuang sampah pada tempatnya. (c) Memilih untuk tidak mengganggu hewan dan tumbuhan di Taman Satwa Bengkulu. 2) Disiplin dengan indikator: (a) Mengikuti aturan dan petunjuk saat berkunjung ke Taman Satwa Bengkulu. (b) Membiasakan mengerjakan tugas tepat waktu. (c) Mengelola waktu yang akan digunakan dalam kunjungan ke Taman Satwa Bengkulu sesuai dengan jarak dan kecepatan. 3) Tanggungjawab dengan indikator: (a) Memberi solusi saat kelompok mengalami masalah. (b) Menunjukkan peran individu dalam mengerjakan tugas kelompok. Dan (c) Membiasakan diri untuk tidak merusak lingkungan sekitar. 4) Kreatif dengan indikator: (a) Membuat gambar sesuai dengan ide kelompok (b) Tidak meniru hasil karya kelompok lain. (c) Berani memutuskan pewarnaan yang bervariasi.

Tabel 1. Pengukuran sikap siswa pada pembelajaran Tematik berbasis Taman Satwa

\begin{tabular}{llcc}
\hline \multirow{2}{*}{ No } & \multirow{2}{*}{ Aspek Sikap yang Diamati } & \multicolumn{2}{c}{$\begin{array}{c}\text { Jumlah siswa yang mencapai } \\
\text { kategori Sangat Baik pada Kelas }\end{array}$} \\
\cline { 3 - 4 } & & $74,28 \%$ & VB \\
\hline 1. & Peduli Lingkungan & $40 \%$ & $36,36 \%$ \\
2. & Disiplin & $31,43 \%$ & $30,30 \%$ \\
3. & Tanggungjawab & $42,86 \%$ & $39,39 \%$ \\
4. & Kreatif & $36,36 \%$ \\
\hline
\end{tabular}

Penilaian pengetahuan terdiri atas (1) menyebutkan 5 nama hewan, makanan dan penggolongan hewan berdasarkan makanannya. (2) Menghitung kecepatan (menit) yang ditempuh masing-masing siswa berikut dari sekolah ke Taman Satwa Bengkulu, menunjukkan rata-rata pada kelas VA sebesar 74,43 dan untuk kelas VB sebesar 74,7.

Penilaian keterampilan mencakup: (1) Membuat Teks Penjelasan Tentang Hewan Karnivora, Herbivora, dan Omnivora dengan indicator: (a) Mengumpulkan informasi yang relevan dengan teks penjelasan yang akan dibuat. (b) Merancang teks penjelasan yang komunikatif dan mudah dipahami. (c) Menggunakan kosakata baku dalam membuat teks penjelasan. (2) Mengisi Tabel Tentang Konsep Kecepatan Sebagai Hasil Bagi Antara Jarak dan Waktu, dengan indicator: (a) Membuat tabel sesuai dengan komponen yang dibutuhkan. (b) Menggunakan rumus tentang konsep kecepatan sebagai hasil bagi antara jarak dan waktu. (c) Menjawab pertanyaan pada tabel dengan jawaban yang relevan. (3) Membuat Laporan Pengamatan Tentang Hewan Karnivora, Herbivora, dan Omnivora di Taman Satwa Bengkulu, dengan indicator: (a) Mengumpulkan data yang dibutuhkan dalam membuat laporan hasil pengamataan. (b) Menyesuaikan sistematika penulisan laporan hasil pengamatan. (c) Merancang laporan hasil pengamatan. (4) Membuat gambar dengan terampil (garis, bentuk dan warna). Dengan descriptor: (a) Terampil membuat sketsa gambar, b) Terampil menyempurnakan gambar, dan c) Terampil mewarnai menggunakan spidol. Hasil pengukuran keterampilan disajikan pada Tabel 2.

Tabel 2. Keterampilan siswa pada pembelajaran Tematik di Taman Satwa 


\begin{tabular}{llcc}
\hline \multirow{2}{*}{ No } & \multirow{2}{*}{ Aspek Keterampilan yang Diamati } & \multicolumn{2}{c}{$\begin{array}{c}\text { J Jumlah siswa yang mencapai } \\
\text { kategori Sangat Baik pada Kelas }\end{array}$} \\
\cline { 3 - 4 } & & VA & VB \\
\hline 1. & Membuat teks penjelasan & $74,28 \%$ & $48,57 \%$ \\
2. & Mengisi table tentang & $40 \%$ & $25,71 \%$ \\
3. & Membuat laporan & $31,43 \%$ & $11,43 \%$ \\
4. & Membuat gambar & $42,86 \%$ & $25,71 \%$ \\
\hline
\end{tabular}

Sikap, Pengetahuan, dan Keterampilan Siswa SDN 04 Kota Bengkulu

Penilaian sikap, pengetahuan, dan keterampilan hasil pembelajaran tematik terintegrasi lingkungan hidup dan biodiversity berbasis ICT (Foto Hewan pada Taman Satwa) pada SDN 04 Kota Bengkulu mencakup sikap, pengetahuan, dan keterampilan. Penilaian sikap digunakan lembar observasi meliputi: (1) Peduli Lingkungan dengan indicator: (a) Membiasakan memungut sampah yang terlihat di sekitar sekolah. (b) Memilih membuang sampah pada tempatnya. (c) Memilih untuk tidak mengganggu hewan dan tumbuhan yang ada di lingkungan sekolah. (2) Disiplin dengan indicator: (a) Mengikuti aturan dan petunjuk saat mengerjakan tugas. (b) Membiasakan mengerjakan tugas tepat waktu. Dan (c) Menyelesaikan hasil gambar tepat waktu. (3) Tanggungjawab dengan indicator: (a) Memberi solusi saat kelompok mengalami masalah. (b) Menunjukkan peran individu dalam mengerjakan tugas kelompok. (c) Membiasakan diri untuk tidak merusak lingkungan sekitar. (4) Kreatif dengan indicator (a) Membuat gambar sesuai dengan ide kelompok (b) Tidak meniru hasil karya kelompok lain. (c) Berani memutuskan pewarnaan yang bervariasi. Hasil pengukuran sikap siswa disajikan pada Tabel 3.

Tabel 3. Pengukuran sikap siswa pada pembelajaran Tematik berbasis ICT

\begin{tabular}{llcc}
\hline \multirow{2}{*}{ No } & Aspek Sikap yang Diamati & \multicolumn{2}{c}{$\begin{array}{c}\text { J Jumlah siswa yang mencapai } \\
\text { kategori Sangat Baik pada Kelas }\end{array}$} \\
\cline { 3 - 4 } & & $86,95 \%$ & VB \\
\hline 1. & Peduli Lingkungan & $52,17 \%$ & $50 \%$ \\
2. & Disiplin & $47,82 \%$ & $54,54 \%$ \\
3. & Tanggungjawab & $47,82 \%$ & $59,09 \%$ \\
4. & Kreatif & $50 \%$ \\
\hline
\end{tabular}

Pengetahuan yang diukur adalah (1) menyebutkan 5 nama hewan, makanan dan penggolongan hewan berdasarkan makanannya. (2) Hitunglah kecepatan (menit) yang ditempuh oleh dua ekor kuda yang menarik delman dari Simpang Lima ke Pantai Panjang. Hasil penilaian pengetahuan siswa yang mengikuti pembelajaran tematik terintegrasi lingkungan hidup dan biodiversity menggunakan sumber belajar ICT video pembelajaran dan permainan menunjukkan rata-rata pada kelas VA sebesar 83,26 dan untuk kelas VB sebesar 78.86 .

Penilaian keterampilan mencakup: (1) Membuat Teks Penjelasan tentang Hewan Karnivora, Herbivora, dan Omnivora, dengan indikator: (a) Mengumpulkan informasi yang relevan dengan teks penjelasan yang akan dibuat. (b) Merancang teks penjelasan yang komunikatif dan mudah dipahami. (c) Menggunakan kosakata baku dalam membuat teks penjelasan. (2) Mengisi Tabel tentang Konsep Kecepatan sebagai Hasil Bagi Antara 
Jarak dan Waktu dengan indikator: (a) Membuat tabel sesuai dengan komponen yang dibutuhkan. (b) Menggunakan rumus tentang konsep kecepatan sebagai hasil bagi antara jarak dan waktu. (c) Menjawab pertanyaan pada tabel dengan jawaban yang relevan. (3) Membuat Laporan Pengamatan tentang Hewan Karnivora, Herbivora, dan Omnivora berdasarkan Hasil Pengamatan Video dengan indikator: (a) Mengumpulkan data yang dibutuhkan dalam membuat laporan hasil pengamataan. (b) Menyesuaikan sistematika penulisan laporan hasil pengamatan. (c) Merancang laporan hasil pengamatan. (4) Membuat gambar dengan terampil (garis, bentuk dan warna). Dengan descriptor: (a) Terampil membuat sketsa gambar, b) Terampil menyempurnakan gambar, dan c) Terampil mewarnai menggunakan spidol.

Tabel 4. Pengukuran Keterampilan siswa pada pembelajaran Tematik berbasis ICT

$\%$ Jumlah siswa yang mencapai

No Aspek Keterampilan yang Diamati kategori Sangat Baik pada Kelas

1. Membuat teks penjelasan

VA VB

2. Mengisi table tentang

$73,9 \%$

$45,45 \%$

3. Membuat laporan

$43,47 \%$

$40,9 \%$

4. Membuat gambar

$52,17 \%$

$40,9 \%$

$56,52 \%$

$36,36 \%$

Langkah-langkah pembelajaran discovery yang mencakup:

(1) Stimulasi, menjadikan: (a) Siswa merespon positif mengamati media animasi hewan. (b) Siswa bertanya jawab dengan aktif mengenai gambar/foto hewan-hewan yang ada di Taman Sarwa Bengkulu.

(2) Identifikasi masalah menjadikan: (a) Siswa merespon positif kunjungan ke Taman Satwa Kota bengkulu. (b) Siswa merespon positif mengenai arahan petunjuk mengerjakan LDS. (c) Siswa antusias dan tertib menuju ke Taman Satwa Bengkulu bersama guru.

(3) Pengumpulan data di Taman Satwa Bengkulu menjadikan: (a) Siswa menyanyikan lagu "Herbivora Hewan Pemakan tumbuhan)". (b) Siswa antusias melakukan mengumpulkan data. (c) Siswa dengan tertib menerima logistik pembelajaran dan dilarang merusak dan mengganggu hewan-hewan yang ada di Taman Sarwa Bengkulu. (d) Kelompok fokus dan tertib melakukan pengamatan tentang hewan-hewan yang ada di Taman Satwa. (e) Siswa antusias dan fokus mengamati ciri-ciri hewan yang ada di masing-masing posko pengamatan).

(4) Pengolahan data, menjadikan: (a) Siswa bersama kelompok tertib menuliskan hasil pengamatannya untuk mengisi LDS. (b) Siswa fokus dan tertib melakukan kegiatan diskusi bersama teman satu kelompoknya tentang anggota gerak, kulit, dan makanan hewan yang diamati.

(5) Pembuktian, menjadikan: (a) Siswa antusias dan fokus mencocokan antara rumusan masalah yang ada di LDS dengan jawaban yang sudah diperoleh dari hasil pengamatan 
dan diskusi. (b) Siswa fokus dan tertib membuat laporan hasil pengamatan di Taman Satwa Bengkulu. (c) Siswa antusias dan tertib berkumpul di depan pintu gerbang Taman Satwa untuk mendapatkan pengarahan dari guru.

(6) Penarikan kesimpulan menjadikan siswa antusias dan bersemangat mengungkapkan apa yang telah didapat serta kesulitan yang ditemui dalam pembelajaran.

Pembelajaran tematik terpadu memiliki karakteristik: (1) berpusat pada siswa (Student Centered); (2) memberikan pengalaman langsung (Direct Experiences); (3) pemisahan mata pembelajaran tidak begitu jelas; (4) menyajikan konsep dari beberapa mata pembelajaran; (5) bersifat fleksibel;(6) hasil pembelajaran sesuai dengan minat kebutuhan siswa; (7) menggunakan prinsip belajar menyenangkan, sesuai dengan karakteristik anak usia sekolah dasar (Trianto, 2010: 91-92). Kualitas pembelajaran tematik integratif menggunakan model diskoveri berbasis ICT ini sesuai dengan pernyataan Winarni (2012: 22-24) bahwa model Discovery Learning adalah didefinisikan sebagai proses pembelajaran yang terjadi bila pelajar tidak disajikan dengan pelajaran dalam bentuk finalnya, tetapi diharapkan mengorganisasi sendiri. Menurut Winarni (2016) bahwa discovery dilakukan melalui observasi, klasifikasi, pengukuran, prediksi, penentuan dan inferi. Untuk menunjang proses belajar perlu lingkungan memfasilitasi rasa ingin tahu siswa pada tahap eksplorasi. Untuk memfasilitasi proses belajar yang baik dan kreatif harus berdasarkan pada manipulasi bahan pelajaran sesuai dengan tingkat perkembangan kognitif siswa.

Manipulasi bahan pembelajaran untuk memfasilitasi kemampuan siswa dalam berpikir sesuai dengan tingkat perkembangannya. Kelebihan penerapan Discovery Learning antara lain adalah: (1) Membantu siswa untuk memperbaiki dan meningkatkan keterampilan dan proses kognitif. (2) Menimbulkan rasa senang pada siswa, karena tumbuhnya rasa menyelidiki. (3) Menyebabkan siswa mengarahkan kegiatan belajarnya sendiri dengan melibatkan akalnya dan motivasi sendiri. (4) Membantu siswa memperkuat konsep dirinya, karena memperoleh kepercayaan bekerja sama dengan yang lainnya. (5) Membantu siswa menghilangkan skeptisme (keragu-raguan) atau pasti. (6) Mengembangkan ingatan dan transfer kepada situasi proses belajar yang baru. (7) Mendorong siswa berpikir dan bekerja atas inisiatif sendiri, berpikir intuisi dan merumuskan hipotesis sendiri. (8) Memberikan keputusan yang bersifat intrinsik. Dan (9) Meningkatkan tingkat penghargaan pada siswa dan mengembangkan bakat dan kecakapan individu.

\section{KESIMPULAN DAN SARAN}

\section{Kesimpulan}

Berdasarkan hasil pembahasan dapat dibuat kesimpulan sebagai berikut:

1) Pelaksanaan pembelajaran tematik terintegrasi PLH dan biodiversity menggunakan sumber belajar Taman Satwa dan ICT yang secara operasional melalui tahap: (a) 
stimulasi dengan menyajikan gambar power point hewan diikuti dengan tanya jawab, (b) Identifikasi masalah secara kelompok berdasarkan hasil tayangan dan tanya jawab,

(c) pengumpulan data baik di Taman Satwa Bengkulu maupun melalui video animasi, (d) pengolahan data untuk menjawab pertanyaan dalam LDS secara kelompok, (e) Pembuktian dengan cara siswa mencocokan antara rumusan masalah yang ada di LDS dengan jawaban yang sudah diperoleh dari hasil pengamatan dan diskusi. Dan terakhir (f) Penarikan kesimpulan mengungkapkan apa yang telah didapat.

2) Pelaksanaan pembelajaran tematik terintegrasi PLH dan pelestarian biodiversity dapat: (a) mengembangkan sikap social siswa yaitu peduli lingkungan, disiplin, tanggungjawab, dan kreatif. (b) Pengetahuan siswa tentang kehidupan hewan karnivora, herbivora, dan omnivora. (c) Keterampilan siswa membuat teks penjelasan tentang hewan karnivora, herbivora, dan omnivora, mengisi tabel, membuat laporan pengamatan, dan membuat gambar dengan terampil (garis, bentuk dan warna).

\section{Saran}

Berdasarkan kesimpulan dapat diberikan saran sebagai berikut:

1. Bagi guru yang ingin melaksanakan pembelajaran tematik menggunakan perangkat pembelajaran dengan Taman Satwa Kota Bengkulu sebagai sumber belajar dapatmengadaptasi perangkat dalam kegiatan ini. Sedangkan bagi guru atau peneliti selanjutnya yang akan menggunakan program Video pembelajaran animasi dan game harus melakukan kontak atau ijin dari tim penyusun.

2. Bagi guru atau peneliti selanjutnya yang akan menggunakan instrument pengukuran sikap dan keterampilan siswa terhadap lingkungan hidup harus melakukan kontak atau ijin dari tim penyusun.

\section{UCAPAN TERIMA KASIH}

Ucapan terima kasih kami sampaikan kepada: (1) Ditjen Penguatan Riset dan Pengembangan Kementerian Riset, Teknologi, dan Pendidikan Tinggi Bidang Riset dan Pengabdian kepada Masyarakat yang telah menyediakan dana pengabdaian kepada masyarakat Hibah IbM Tahun 2016. (2) Rektor Universitas Bengkulu melalui Lembaga Penelitian dan Pengabdian Kepada Masyarakat yang telah memfasilitasi terlaksanannya kegiatan pengabdian kepada masyarakat baik secara teknis maupun administratif. (3) Kepala Sekolah, Guru, dan siswa kelas V SDN 04 Kota Bengkulu. (4) Kepala Sekolah, Guru, dan siswa kelas V SDN 20 Kota Bengkulu yang telah menjadi mitra kegiatan IbM tahun 2016.

\section{DAFTAR PUSTAKA}

Trianto, 2010, Mengembangkan Model Pembelajaran Tematik, Prestasi Pustaka, Jakarta. 
Winarni, E.W., Daimun, V. Karjiyati, 2015, IbM Penanaman Prinsip Re-duce, Re-use, dan Re-cycle (3R) dengan Pembuatan karya Kolase dalam Pembelajaran Tematik di SD, Laporan IbM Hibah Dikti, Bengkulu.

Winarni, E.W., F. Noperman, E.P. Purwandari, 2014, Pengembangan Buku IPA SD Berbasis Inkuiri untuk Meningkatkan Sikap Ilmiah, Berpikir Kritis, Pemahaman Konsep, Kesadaran Lingkungan, dan Fenomena Alam, Laporan Penelitian Hibah Kompetensi Tahun ke III, Hibah Dikti, Bengkulu.

Winarni, E.W., 2012, Inovasi dalam Pembelajaran IPA, FKIP, Unib Press, ISBN 978-6028043-29-8. Bengkulu.

Winarni, E.W., 2016a, Paradigma Pembelajaran Abad 21 "Inovatif, Kreatif, Produktif, dan Afektif”, Prosiding Seminar Nasional Universitas Muhamadiyah Palembang, Vol. 1 No.1 TH. JAN-DES 2016 ISSN: 2527-7553, Palembang.

Winarni, E.W., 2016b, Environment-based Character Education to Build Future Generation's Competent, International Conference on Education and Psychology Universiti Malaysia Sabah Kota Kinabalu, Programme Book International Conference on Education and Psychology. 